\title{
Д.
}

\section{The effect of software version on the rate of temperature pulldown in Starcare banana shipments}

Dr. ir. Leo Lukasse, M.G. Staal

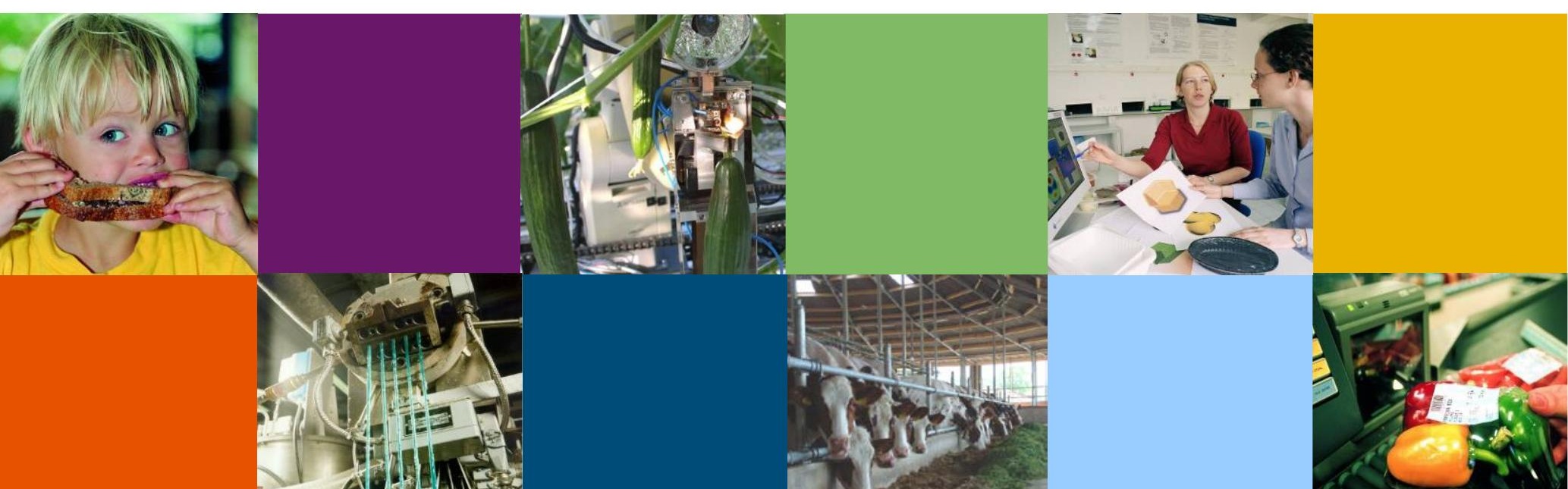




\section{Colophon}

Title

Author(s)

Number

Date of publication

Version

Confidentiality

Project number

Approved by

Review

Name reviewer

Client
The effect of software version on the rate of temperature pulldown in Starcare banana shipments

Dr. ir. Leo Lukasse, M.G. Staal

1752

July 2017

2.0

Yes, till three years after date of publication

6239044900

Ir. Janneke de Kramer

Internal

Ir. Eelke Westra

Maersk Line

Wageningen Food \& Biobased Research

P.O. Box 17

NL-6700 AA Wageningen

Tel: +31 (0)317480084

E-mail: info.fbr@wur.nl

Internet: www.wur.nl/foodandbiobased-research

(C) Wageningen Food \& Biobased Research, institute within the legal entity Stichting Wageningen Research All rights reserved. No part of this publication may be reproduced, stored in a retrieval system of any nature, or transmitted, in any form or by any means, electronic, mechanical, photocopying, recording or otherwise, without the prior permission of the publisher. The publisher does not accept any liability for inaccuracies in this report.

This report can be downloaded for free from July 2020 at https://doi.org/10.18174/563051/ or at www.wur.nl/ wfbr (under publications). 


\section{Abstract}

This report covers a series of climate chamber tests addressing the question why software version 0349_07 yields faster temperature pulldown in Starcare CA shipments of bananas than software version 0351_23. On beforehand three possible reasons were postulated:

1. Change in evaporator fan speed control.

2. Change in maximum refrigeration capacity.

3. Change in supply air temperature distribution across the width of the container. A series of 20 tests was ran in the period from 11-04-2017 till 23-04-2017. During all tests 56 temperature sensors (PT100) recorded temperatures at a one minute interval. In principle each test was only terminated after all temperatures had been in steady state for at least four hours. Based on the results it is concluded that:

1. There indeed is a change in evaporator fan speed control. This may explain a difference in temperature pulldown occurring in the later stages of the pulldown, after Treturn reduces below Tsupply $+1.2^{\circ} \mathrm{C}$.

2. There seems to be a change in maximum refrigeration capacity, which could explain the difference in temperature pulldown. It is not believed this difference has much impact on the rate of temperature pulldown in banana shipments, because usually in those shipments the unit hardly needs to call upon the maximum refrigeration capacity.

3. The software version does not affect the supply air temperature distribution across the width of the container.

To find out which effect is strongest, the difference in evaporator fan speed control or the reduction in maximum refrigeration capacity, it is recommended to perform a 'big data' analysis on numerous Starcare CA downloads (RCM data) of software 0349_07 and later software versions. 


\section{Content}

$\begin{array}{ll}\text { Abstract } & 3\end{array}$

1 Introduction 5

2 Materials and methods $\quad 6$

2.1 Materials 6

2.1.1 Container, unit and chamber 6

2.1.2 Internal heaters 8

2.1.3 Temperature sensors 8

2.1.4 Measuring and power apparatus 9

$\begin{array}{ll}2.2 \text { Methods, i.e. test program } & 10\end{array}$

3 Results 12

3.1 U-value 13

$\begin{array}{lll}3.2 & \text { Evaporator fan speed } & 14\end{array}$

3.3 Maximum refrigeration capacity 14

3.4 Supply air temperature differences across the width of the container 15

4 Discussion 21

5 Conclusions 23

6 Recommendations $\quad 24$

$\begin{array}{ll}\text { Acknowledgements } & 25\end{array}$ 


\section{Introduction}

This report covers a series of climate chamber tests addressing the question why software version 0349_07 yields faster temperature pulldown in Starcare CA shipments of bananas than software version 0351_23.

On beforehand Morten Baerentz (Maersk Line) had strong indications that the rate of temperature pulldown in Starcare banana shipments is faster in software version 0349_07 than in newer software versions. Therefore he asked WFBR to propose and conduct a series of climate chamber tests to study if and how software version affects the rate of temperature pulldown. It was Morten Baerentz's choice to compare the \pm five years old software version 0349_07 to the brand-new beta software version 0351_23 (received from Starcool on 04-04-2017). He also chose to limit the scope to Starcare banana shipments, i.e. Starcool CIM6 equipment with Tset $=14.0$ ${ }^{\circ} \mathrm{C}$, and $\mathrm{CA}$ activated using $\mathrm{O} 2 \mathrm{set}=3.0 \%$ and $\mathrm{CO} 2 \mathrm{set}=4.0 \%$.

How could software affect the rate of temperature pulldown? On beforehand the following possible reasons were identified:

1. Change in evaporator fan speed control.

2. Change in maximum refrigeration capacity by modified limits imposed on maximum compressor frequency.

3. Change in supply air temperature distribution across the width of the container, due to changes in superheat control.

In earlier software acceptance tests the Quest II evaporator fan speed control was tested, and over the years no difference was observed. But the software 0349_07 (released in approximately 2011) was never climate chamber tested, as the first CIM6 software version which was climate chamber tested was software 351_05 (in 2013). Moreover, the authors have a remote memory that there once was a software version which forced evaporator fans to high speed in CA mode. Maybe that was software version 0349_07.

It is hard to imagine how maximum refrigeration capacity could have a significant effect on the rate of temperature pulldown. In banana shipments supply air temperature usually reaches setpoint nearly immediately after power up. From that moment on the unit no longer calls upon its maximum refrigeration capacity.

The impression is that Starcool has made changes in the superheat control with the objective to protect the compressor. That happened about two years ago. It has never been tested how that works out in supply air temperature distribution across the width of the container.

The aim of this study is to find out if one of the three possible reasons listed above yields software version 0349_07 a faster rate of temperature pulldown in Starcare banana transports than software version 0351_23. 


\section{$2 \quad$ Materials and methods}

\subsection{Materials}

\subsubsection{Container, unit and chamber}

Maersk Line has provided an empty $40 \mathrm{ft}$. high-cube Starcare reefer container for the test. The position of the unit's supply air temperature sensors was visually checked. These are positioned above T-bar opening 27 (opening 1 is at the unit's controller side).

Also provided is a Maersk Line clip-on diesel generator set (genset), which is detached from the reefer and placed outside the test facility. See Table 1 and Table 2 for more details.

Table 1, photos of tested equipment.

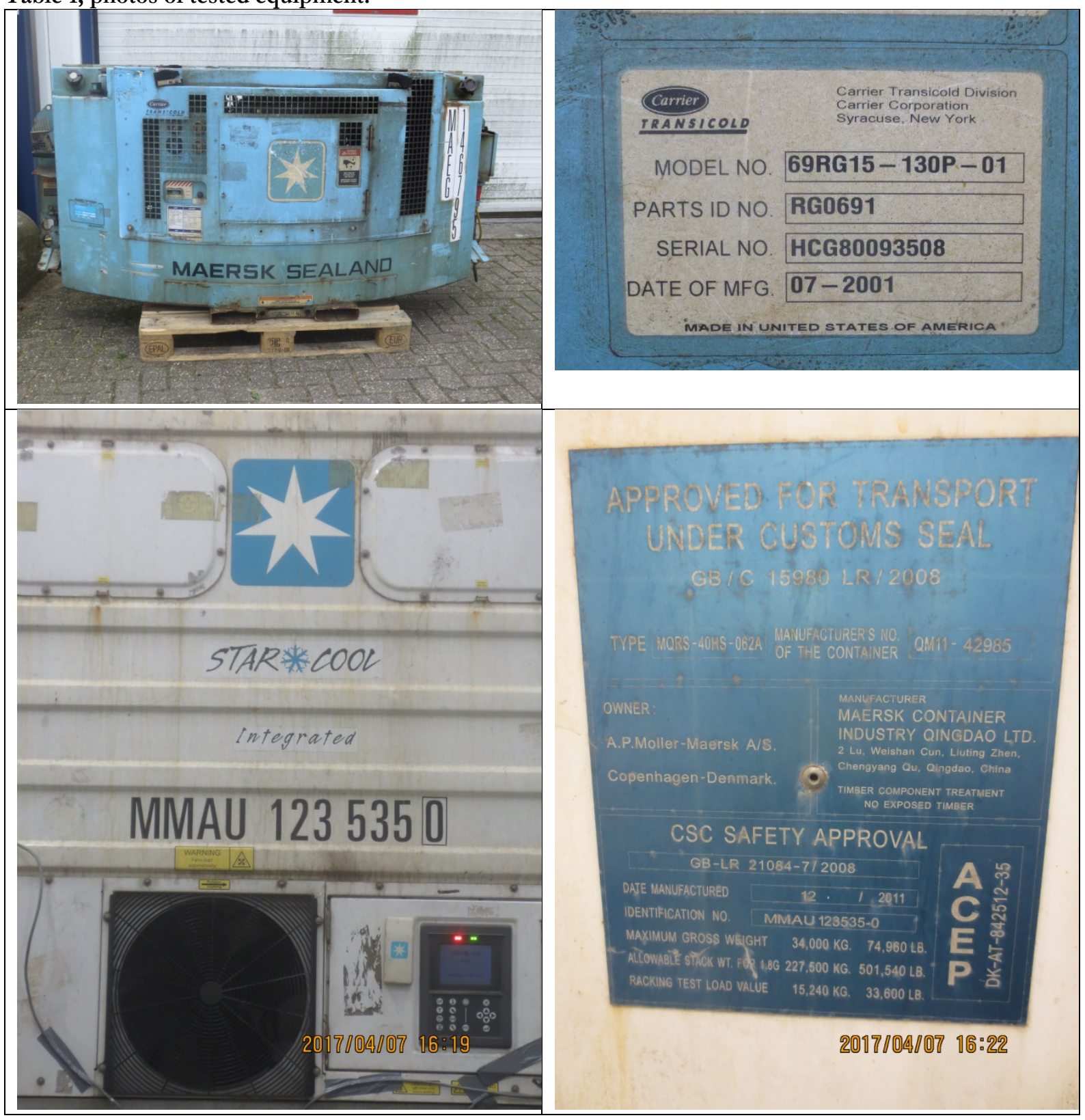




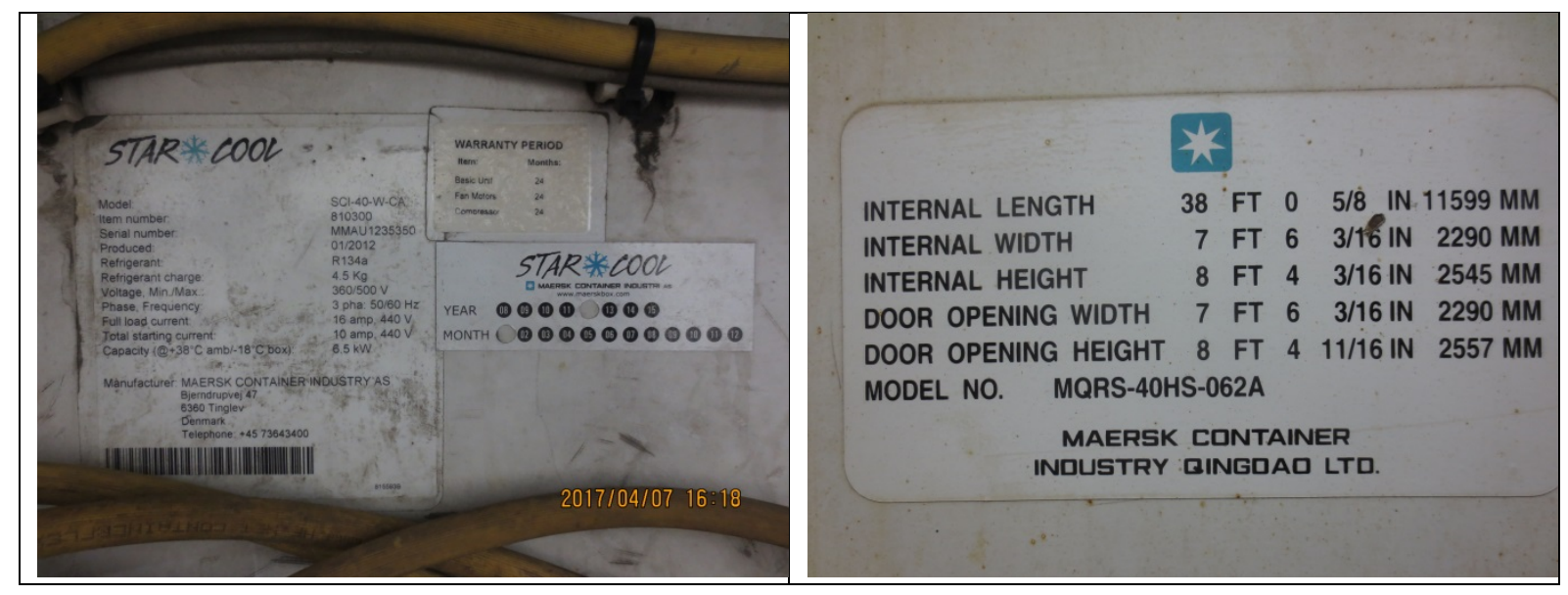

Table 2, characteristics of equipment used in tests.

\begin{tabular}{|l|l|l|l|l|}
\hline & manufacturer & man. date & model no. & identification no. \\
\hline container & N/A & N/A & N/A & MMAU123535[0] \\
\hline unit & Starcool & Jan. 2012 & SCI-40-W-CA & MMAU1235350 \\
\hline box & MCI Qingdao & July 2005 & MQRS-40HS-062A & QM11-42985 \\
\hline genset & Carrier & July 2001 & 69RG15-130P-01 & MAEG146795 \\
\hline
\end{tabular}

The test facility consists of an insulated chamber (Fig. 1) large enough to house the $40 \mathrm{ft}$. container including chassis. During testing, the air temperature in the chamber (henceforth referred to as external temperature) is controlled with the aim to maintain the air inlet temperature to the unit's condenser $\mathrm{T}_{\text {condenser_in }}$ at a constant value.
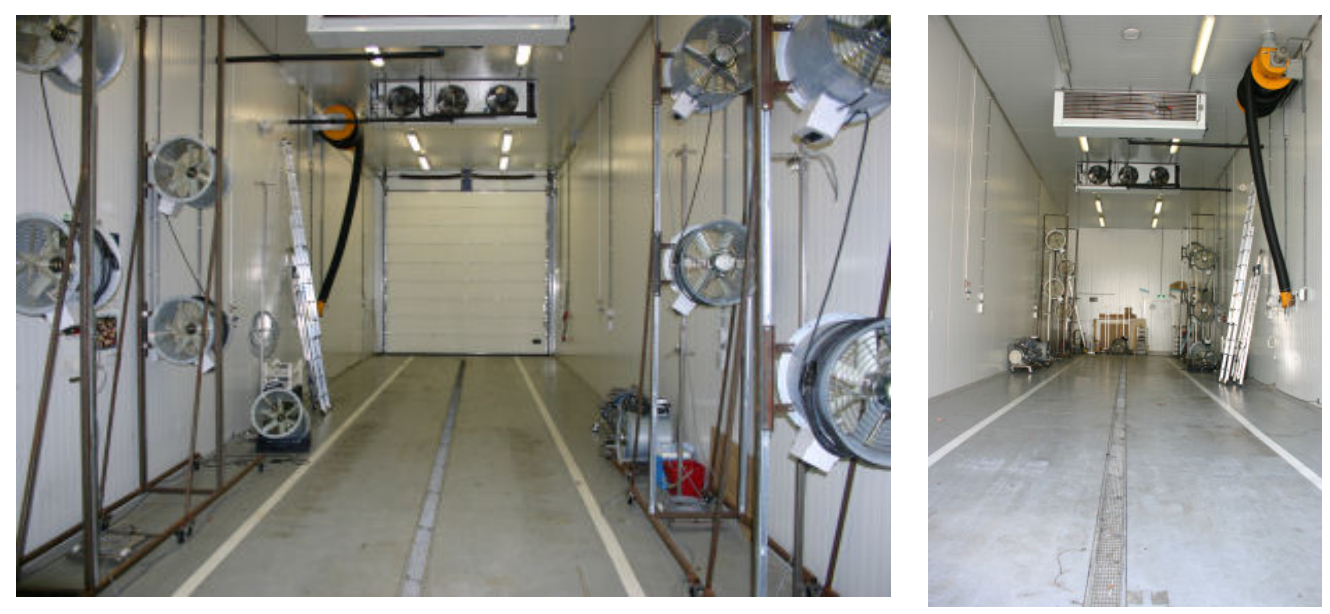

Fig. 1, climate chamber used. 


\subsubsection{Internal heaters}

The internal heat production in the container is manipulated by placing four controllable electrical fan heaters (maximum capacity $2.7 \mathrm{~kW}$ each) in the container. The power assigned to the four red heaters in Fig. 2 is continuously adjustable in the range $0 \sim 2.7 \mathrm{~kW}$ by means of a 0 $\sim 10 \mathrm{~V}$ control voltage signal. During some tests, demanding a very high internal heat production, a large manually set fifth heater is added. See Fig. 2.

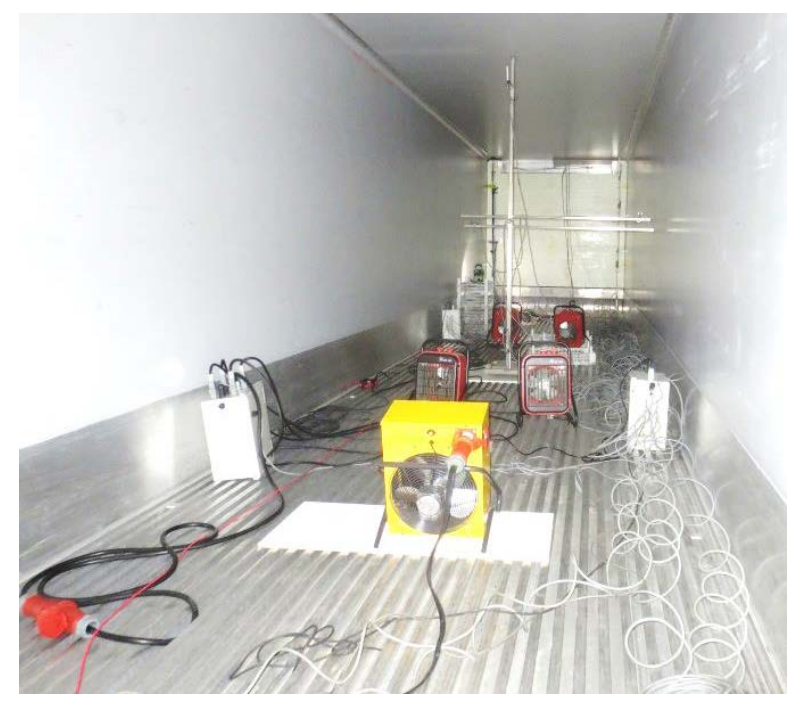

Fig. 2, five internal heaters: four red heaters are automatically fully controllable from 0 till $2.7 \mathrm{~kW}$, one yellow heater is manually set at approximately $0,3,6,9$ or $12 \mathrm{~kW}$.

\subsubsection{Temperature sensors}

During all tests temperature is monitored at a one minute log interval in the following locations:

1. 12 sensors measure the external temperature around the container at $10 \mathrm{~cm}$ from the walls: at the eight corners and at the centre of the four largest surfaces.

2. 4 sensors evenly distributed over the condenser inlet measure the condenser air inlet temperature.

3. 12 sensors measure the internal temperature in the container at $10 \mathrm{~cm}$ from the walls: at the eight corners and at the centre of the four largest surfaces.

4. 4 sensors, evenly distributed over the return air grid, measure the unit's return air temperature.

5. 18 sensors measure supply air temperature between T-bars at a distance of $30 \mathrm{~cm}$ from the T-bar inlet (see Fig. 4).

6. 6 sensors measure temperature in ballistic gel packs (to simulate product), placed on the T-bar at the end of the 1 meter long T-bar cover.

All temperature sensors are PT100 temperature sensors (www.tempcontrol.nl, model PT-8316/S, class A) with an accuracy $\pm 0.25^{\circ} \mathrm{C}$. See Fig. 3 . 
A piece of plywood $(\mathrm{L} \times \mathrm{W}=100 \times 228 \mathrm{~cm})$ covers the T-bars at the unit-end over the complete width of the container. Duct tape seals the connections with the baffle plate and the side walls. Temperature sensors are placed at $30 \mathrm{~cm}$ from the T-bar entrance. The PT100 measurement tips are in the centre of the air duct between two T-bars.

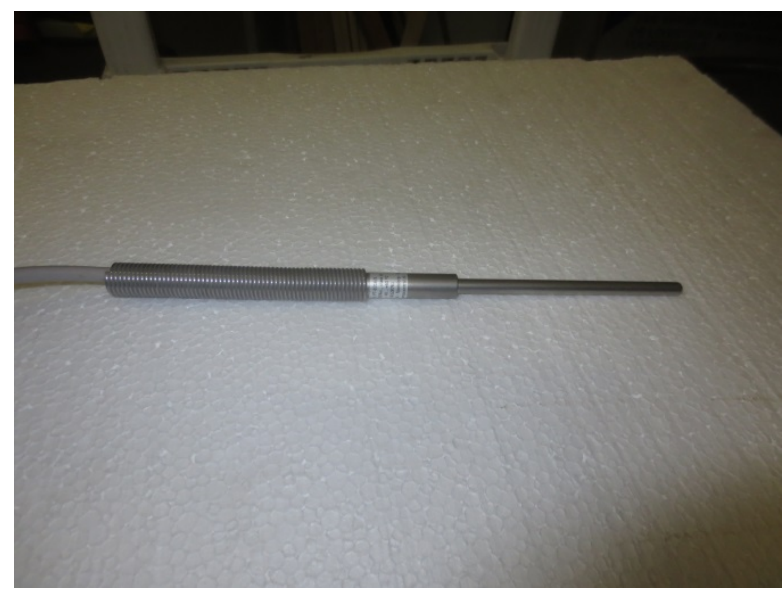

Fig. 3, a PT100 temperature sensor.

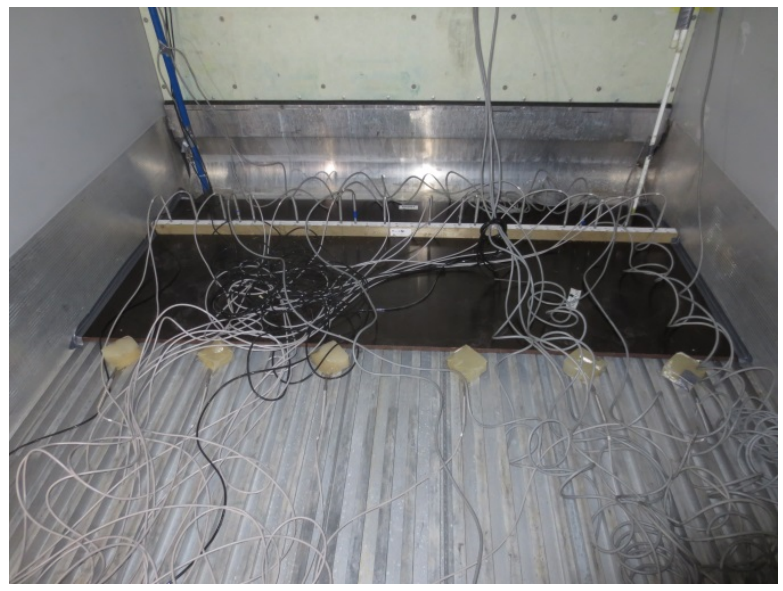

Fig. 4, 18 temperature sensors placed in T-bar openings, and 6 sensors placed in ballistic gel packs.

\subsubsection{Measuring and power apparatus}

The internal data from the temperature sensors is logged using a first series of FieldPoint data logging modules, which are placed inside the container. To provide the inside modules and the four controllable internal heaters with power, a $400 \mathrm{~V}$ power supply is lead into the container. It is connected to the mains power through a flat cable which fits through the container door gaskets. The total electrical power used by all apparatuses inside the container is logged by a Zimmer ZES power meter placed outside the container (Fig. 5). The additional, manually set, yellow fifth heater is fed through a second flat power cable. In tests where the additional, manually set, yellow heater was used, the electric power uptake of that heater was measured by a second Zimmer ZES power meter. The external temperature data from the sensors and the power uptake data are logged using a second series of FieldPoint data logging modules, which are placed outside the container.

All data is recorded by the FieldPoint modules. The reefer unit variables are monitored in Starcool's PClog and the unit's datalog. 


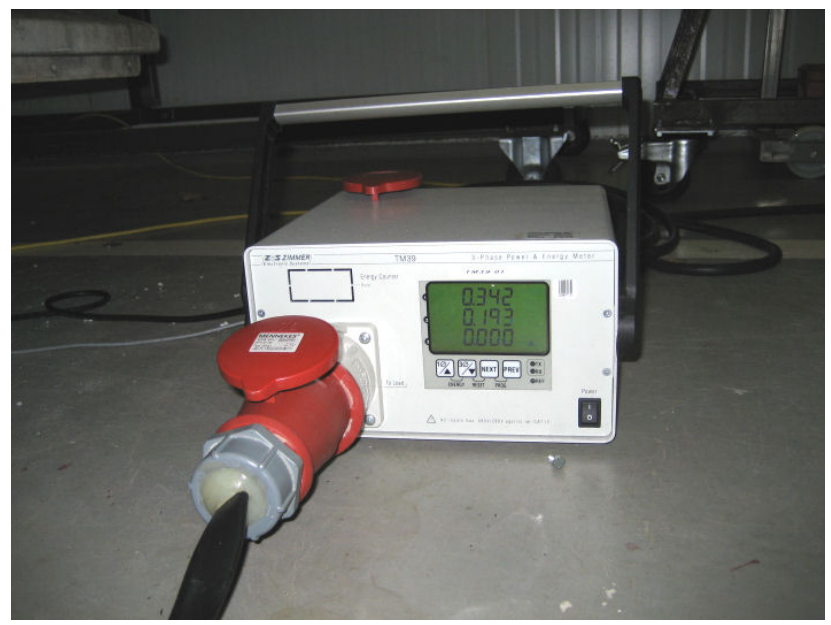

Fig. 5, ZES power meter used.

\subsection{Methods, i.e. test program}

On beforehand there was a test plan. As always unexpected situations occurred during testing, necessitating deviations from the original plan. Moreover intermediate results gave reasons to add new tests. The original test plan is omitted from this report. Table 3 lists all tests as they have been performed in consecutive order, including the aim of the test. Note that test 17 , at nearly the end of the test series, is a pure repetition of test 2 . The aim of this repetition is to verify that the machine characteristics have not changed during the tests series, e.g. due to refrigerant loss. The aim was to only terminate a test after all temperatures had been in steady state for at least four hours.

Table 3, test program. Col. 1 lists the test number. Col. 2 till 7 specify the test conditions. The last column describes the aim of the test.

\begin{tabular}{|c|c|c|c|c|c|c|c|}
\hline $\begin{array}{l}\text { test } \\
\text { no. }\end{array}$ & software & $\begin{array}{l}\text { air temp } \\
\text { a cond. } \\
\text { inlet } \\
{\left[{ }^{\circ} \mathrm{C}\right]}\end{array}$ & $\begin{array}{c}\text { setpoint } \\
\text { Reefer } \\
{\left[{ }^{\circ} \mathrm{C}\right]}\end{array}$ & $\begin{array}{l}\mathrm{f}_{\text {power }} \\
{[\mathrm{Hz}]}\end{array}$ & $\begin{array}{l}\text { active } \\
\text { appl. }\end{array}$ & $\begin{array}{l}\text { internal } \\
\text { heater } \\
\text { control }\end{array}$ & aim \\
\hline 1 & S0351_23 & 38 & 0.0 & & $60 \mathrm{CA}$ & $\begin{array}{l}\text { regulated } \\
\text { to balance } \\
\text { max. refr. } \\
\text { cap. }\end{array}$ & Maximum refrigeration capacity \\
\hline 2 & S0351_23 & 38 & 14.0 & & \begin{tabular}{l|l|l}
60 & $C A$ \\
\end{tabular} & $0 \mathrm{~V}$ & Tsup differences across width \\
\hline 3 & S0349_07 & 38 & 14.0 & & $60 \mathrm{CA}$ & $0 \mathrm{~V}$ & Tsup differences across width \\
\hline 4 & S0349_07 & 38 & 14.0 & & 60 off $)$ & $0 \mathrm{~V}$ & $\begin{array}{l}\text { Does deactivating CA change } \\
\text { control mode from non-Quest } \\
\text { to Quest II? }\end{array}$ \\
\hline 5 & S0349_07 & 38 & 14.0 & & \begin{tabular}{l|l|}
60 & $\mathrm{CA}$ \\
\end{tabular} & $5 \mathrm{~V}$ & Tsup differences across width \\
\hline 6 & S0349_07 & 38 & 0.0 & & $50 \mathrm{CA}$ & $\begin{array}{l}\text { regulated } \\
\text { to max. } \\
\text { refr. cap. }\end{array}$ & Maximum refrigeration capacity \\
\hline 7 & S0349_07 & 38 & 14.0 & & 60) CA & $8 \mathrm{~V}$ & Tsup differences across width \\
\hline
\end{tabular}




\begin{tabular}{|c|c|c|c|c|c|c|c|}
\hline $\begin{array}{l}\text { test } \\
\text { no. }\end{array}$ & software & $\begin{array}{l}\text { air temp } \\
@ \text { cond. } \\
\text { inlet } \\
{\left[{ }^{\circ} \mathrm{C}\right]}\end{array}$ & $\begin{array}{c}\text { setpoint } \\
\text { Reefer } \\
{\left[{ }^{\circ} \mathrm{C}\right]}\end{array}$ & $\begin{array}{l}\mathrm{f}_{\text {power }} \\
\text { [Hz] }\end{array}$ & $\begin{array}{l}\text { active } \\
\text { appl. }\end{array}$ & $\begin{array}{l}\text { internal } \\
\text { heater } \\
\text { control }\end{array}$ & aim \\
\hline 8 & S0349_07 & 38 & 14.0 & & $60 \mathrm{CA}$ & $2 \mathrm{~V}$ & Tsup differences across width \\
\hline 9 & S0351_23 & 38 & 2.0 & & $50 \mathrm{CA}$ & $\begin{array}{l}\text { regulated } \\
\text { to max. } \\
\text { refr. cap. }\end{array}$ & Maximum refrigeration capacity \\
\hline 10 & $\begin{array}{l}\text { S0349_07/ } \\
\text { S0351_23 }\end{array}$ & 50 & 14.0 & & 60CA & $\begin{array}{l}0 \mathrm{~V}+50 \% \\
\text { of } 12 \mathrm{~kW}\end{array}$ & Tsup differences across width \\
\hline 11 & unit OFF, & 7.5 & 32.5 & & & $\begin{array}{l}0 \mathrm{~V}+50 \% \\
\text { of } 12 \mathrm{~kW}\end{array}$ & $\begin{array}{l}\text { U-value, needed to calculate } \\
\text { maximum refrigeration capacity }\end{array}$ \\
\hline 12 & S0351_23 & 14 & 14.0 & & $60 \mathrm{CA}$ & $0 \mathrm{~V}$ & $\begin{array}{l}\text { eva. fan speed control: Quest or } \\
\text { non-Quest? }\end{array}$ \\
\hline 13 & S0349_07 & 14 & 14.0 & & $60 \mathrm{CA}$ & $0 \mathrm{~V}$ & $\begin{array}{l}\text { eva. fan speed control: Quest II } \\
\text { or non-Quest? }\end{array}$ \\
\hline 14 & S0351_23 & 38 & 14.0 & & $60 \mathrm{CA}$ & $2 \mathrm{~V}$ & Tsup differences across width \\
\hline 15 & S0351_23 & 38 & 14.0 & & 60CA & $5 \mathrm{~V}$ & Tsup differences across width \\
\hline 16 & S0351_23 & 38 & 14.0 & & $60 \mathrm{CA}$ & $8 \mathrm{~V}$ & Tsup differences across width \\
\hline 17 & S0351_23 & 38 & 14.0 & & $60 \mathrm{CA}$ & $0 \mathrm{~V}$ & $\begin{array}{l}\text { redo test } 2 \text { as verification that } \\
\text { machine characteristic has not } \\
\text { changed during the test series. }\end{array}$ \\
\hline 18 & S0351_23 & 38 & 14.0 & & \begin{tabular}{l|l|l}
50 & $\mathrm{CA}$ \\
\end{tabular} & $8 \mathrm{~V}$ & Tsup differences across width \\
\hline 19 & S0351_23 & 50 & 14.0 & & $60 \mathrm{CA}$ & $0 \mathrm{~V}$ & Tsup differences across width \\
\hline 20 & S0349_07 & 50 & 14.0 & & $60 \mathrm{CA}$ & $0 \mathrm{~V}$ & Tsup differences across width \\
\hline
\end{tabular}




\section{Results}

The tests series ran from 11-04-2017 till 23-04-2017. During testing the refrigeration unit generated quite some alarms, making it irresponsible to blindly trust the test results. Therefore all test results have been analysed for their trustworthiness. Moreover the results of tests 2 and 17, which should be the same, have been compared. It was observed that the difference between the results of tests 2 and 17 are negligible indeed. Table 4 summarizes the test results, only in terms of whether the test succeeded or not. More details follow in the following subsections.

Table 4, results. Col. 1 till 7 are identical to Table 3: test number in col. 1, and test conditions in col. 2 till 7.

The last column evaluates the test results in terms of their reliability.

\begin{tabular}{|c|c|c|c|c|c|c|c|}
\hline $\begin{array}{l}\text { test } \\
\text { no. }\end{array}$ & software & $\begin{array}{l}\text { air temp } \\
\text { a cond. } \\
\text { inlet } \\
{\left[{ }^{\circ} \mathrm{C}\right]}\end{array}$ & $\begin{array}{l}\text { setpoint } \\
\text { Reefer } \\
{\left[{ }^{\circ} \mathrm{C}\right]} \\
\end{array}$ & $\begin{array}{l}\mathrm{f}_{\text {power }} \\
{[\mathrm{Hz}]}\end{array}$ & $\begin{array}{l}\text { active } \\
\text { appl. }\end{array}$ & $\begin{array}{l}\text { internal } \\
\text { heater } \\
\text { control } \\
\end{array}$ & reliability of test results \\
\hline 1 & S0351_23 & 38 & 0.0 & & $60 \mathrm{CA}$ & $\begin{array}{l}\text { regulated } \\
\text { to balance } \\
\text { max. refr. } \\
\text { cap. }\end{array}$ & $\begin{array}{l}\text { Test aborted because of FC } \\
\text { phase detection alarms. Failed. }\end{array}$ \\
\hline 2 & S0351_23 & 38 & 14.0 & & $60 \mathrm{CA}$ & $0 \mathrm{~V}$ & $\begin{array}{l}\text { Active alarm 'Tsuc invalid', } \\
\text { Tsuc substituted by Tevap. } \\
\text { Effect on data not noticeable. }\end{array}$ \\
\hline 3 & S0349_07 & 38 & 14.0 & & 60 CA & $0 \mathrm{~V}$ & ok \\
\hline 4 & S0349_07 & 38 & 14.0 & & \begin{tabular}{l|l} 
std $(=$ \\
60 off $)$
\end{tabular} & $0 \mathrm{~V}$ & ok \\
\hline 5 & S0349_07 & 38 & 14.0 & & $60 \mathrm{CA}$ & $5 \mathrm{~V}$ & $\mathrm{ok}$ \\
\hline 6 & S0349_07 & 38 & 0.0 & & 50CA & $\begin{array}{l}\text { regulated } \\
\text { to max. } \\
\text { refr. cap. }\end{array}$ & ok \\
\hline 7 & S0349_07 & 38 & 14.0 & & $60 \mathrm{CA}$ & $8 \mathrm{~V}$ & ok \\
\hline 8 & S0349_07 & 38 & 14.0 & & $60 \mathrm{CA}$ & $2 \mathrm{~V}$ & ok \\
\hline 9 & S0351_23 & 38 & 2.0 & & $50 \mathrm{CA}$ & $\begin{array}{l}\text { regulated } \\
\text { to max. } \\
\text { refr. cap. }\end{array}$ & ok \\
\hline 10 & $\begin{array}{c}\text { S0349_07/ } \\
\text { S0351_23 }\end{array}$ & 50 & 14.0 & & $60 \mathrm{CA}$ & $\begin{array}{l}0 \mathrm{~V}+50 \% \\
\text { of } 12 \mathrm{~kW}\end{array}$ & $\begin{array}{l}\text { Not a proper steady state. } \\
\text { Multiple alarms. Test results not } \\
\text { used. }\end{array}$ \\
\hline 11 & unit OFF, & 7.5 & 32.5 & & & $\begin{array}{l}0 \mathrm{~V}+50 \% \\
\text { of } 12 \mathrm{~kW}\end{array}$ & $\begin{array}{l}\text { ok. Not exactly according to } \\
\text { ATP, but fine for our purpose. }\end{array}$ \\
\hline 12 & S0351_23 & 14 & 14.0 & & $60 \mathrm{CA}$ & $0 \mathrm{~V}$ & $\begin{array}{l}\text { Active alarm 'Tsuc invalid', } \\
\text { Tsuc substituted by Tevap. } \\
\text { Effect on data not noticeable }\end{array}$ \\
\hline
\end{tabular}




\begin{tabular}{|c|c|c|c|c|c|c|c|}
\hline $\begin{array}{l}\text { test } \\
\text { no. }\end{array}$ & software & $\begin{array}{l}\text { air temp } \\
\text { a cond. } \\
\text { inlet } \\
{\left[{ }^{\circ} \mathrm{C}\right]}\end{array}$ & $\begin{array}{c}\text { setpoint } \\
\text { Reefer } \\
{\left[{ }^{\circ} \mathrm{C}\right]}\end{array}$ & $\begin{array}{l}f_{\text {power }} \\
{[\mathrm{Hz}]}\end{array}$ & $\begin{array}{l}\text { active } \\
\text { appl. }\end{array}$ & $\begin{array}{l}\text { internal } \\
\text { heater } \\
\text { control }\end{array}$ & reliability of test results \\
\hline 13 & S0349_07 & 14 & 14.0 & & $60 \mathrm{CA}$ & $0 \mathrm{~V}$ & ok \\
\hline 14 & S0351_23 & 38 & 14.0 & & $60 \mathrm{CA}$ & $2 \mathrm{~V}$ & ok \\
\hline 15 & S0351_23 & 38 & 14.0 & & $60 \mathrm{CA}$ & $5 \mathrm{~V}$ & ok \\
\hline 16 & S0351_23 & 38 & 14.0 & & $60 \mathrm{CA}$ & $8 \mathrm{~V}$ & $\begin{array}{l}\text { failed to reach setpoint, not a } \\
\text { proper steady state, only active } \\
\text { alarm is 'Tret invalid' }\end{array}$ \\
\hline 17 & S0351_23 & 38 & 14.0 & & $60 \mathrm{CA}$ & $0 \mathrm{~V}$ & ok \\
\hline 18 & S0351_23 & 38 & 14.0 & & $50 \mathrm{CA}$ & $8 \mathrm{~V}$ & $\begin{array}{l}\text { not a proper steady state, } \\
\text { temperatures gradually rising }\end{array}$ \\
\hline 19 & S0351_23 & 50 & 14.0 & & $60 \mathrm{CA}$ & $0 \mathrm{~V}$ & $\mathrm{ok}$ \\
\hline 20 & S0349_07 & 50 & 14.0 & & $60 \mathrm{CA}$ & $0 \mathrm{~V}$ & $\begin{array}{l}\text { Alarm 'Tinternal HIGH' } \\
\text { continues to toggle between } \\
\text { active and inactive. Effect on } \\
\text { data not visible }\end{array}$ \\
\hline
\end{tabular}

\subsection{U-value}

On beforehand it was planned to just assume a U-value, but circumstances made that it took hardly any extra effort to measure it. The measured value helps to assess refrigeration capacity more accurately. Therefore the U-value was measured (test 11), not exactly according to ATP specification, but yet accurate. The measured $\mathrm{U}$-value is $50 \mathrm{~W} / \mathrm{K}$, for more details see Table 5 .

Table 5, U-value measurement.

\begin{tabular}{|l|l|}
\hline Test method & inner heating \\
\hline Start time of steady state conditions (yyyy-mm-dd hh:mm:ss) & $2017-04-168: 10$ \\
\hline End time of steady state conditions (yyyy-mm-dd hh:mm:ss) & $2017-04-1620: 30$ \\
\hline Duration of steady state conditions (yyyy-mm-dd hh:mm:ss) & $0000-00-0012: 20$ \\
\hline Mean outside temperature of container & $7.80{ }^{\circ} \mathrm{C}$ \\
\hline Maximum difference between two mean outside temperatures & $0.52{ }^{\circ} \mathrm{C}$ \\
\hline $\begin{array}{l}\text { Maximum difference between two outside measurement } \\
\text { locations }\end{array}$ & $2.21{ }^{\circ} \mathrm{C}$ \\
\hline Mean inside temperature of body & $39.59{ }^{\circ} \mathrm{C}$ \\
\hline Maximum difference between two mean inside temperatures & $4.16{ }^{\circ} \mathrm{C}$ \\
\hline $\begin{array}{l}\text { Maximum difference between two inside measurement } \\
\text { locations }\end{array}$ & $5.99{ }^{\circ} \mathrm{C}$ \\
\hline Mean temperature difference achieved & $31.79{ }^{\circ} \mathrm{C}$ \\
\hline Electric power consumption (heaters + fans) & $1595.4 \mathrm{~W}$ \\
\hline Total heat leakage rate $\mathbf{U}\left(\mathbf{W} /{ }^{\circ} \mathbf{C}\right)$ & $\mathbf{5 0 . 1 9} \mathbf{W} / \mathbf{K}$ \\
\hline
\end{tabular}




\subsection{Evaporator fan speed}

For both software versions a test was ran at very low heat load ${ }^{1}$ (tests 12 and 13), because at low heat load Quest II reduces evaporator fan speed to LOW, and hence the difference between Quest II and non-Quest will be clearest. See Table 6 for a summary of the test results. Both in the datalog and the PClogs it is observed that only software 0349_07 runs control mode nonQuest, resulting in high speed evaporator fans. Software 0349_07 runs non-Quest, because CA is active. Already in test 3 and 4 it was verified that activating CA automatically disables Quest II in software 0349_07.

Table 6, summary of test results on evaporator fan speed at low heat load.

\begin{tabular}{|l|l|l|}
\hline software & 349_07 & 351_23 \\
\hline test start & 19-04-2017 04:05 & 18-04-2017 12:09 \\
\hline test end & $19-04-2017$ 09:05 & 18-04-2017 16:53 \\
\hline achieved nett heat load & $0.7 \mathrm{~kW}$ & $-0.1 \mathrm{~kW}$ \\
\hline observed control mode & non-Quest & Quest II \\
\hline $\begin{array}{l}\text { observed evap. fan speed @ } \\
\text { approx.0 W heat load }\end{array}$ & high & alternating high/low \\
\hline
\end{tabular}

\subsection{Maximum refrigeration capacity}

For both software versions the maximum refrigeration capacity was assessed (tests 6 and 9). See Table 7 for results.

Table 7, measured maximum refrigeration capacity @ $\mathbf{T}_{\text {air_inlet_to_condenser }}=38^{\circ} \mathrm{C}, \mathbf{T}_{\text {supply_air }}=14^{\circ} \mathrm{C}, \mathrm{f}_{\text {power }}=50$ Hz.

\begin{tabular}{|l|l|l|l|l|}
\hline software & $\begin{array}{l}\text { power } \\
\text { internal } \\
\text { heaters }[\mathbf{k W}]\end{array}$ & $\begin{array}{l}\text { mean temperature } \\
\text { around the container } \\
{\left[{ }^{\circ} \mathbf{C}\right]}\end{array}$ & $\begin{array}{l}\text { mean internal } \\
\text { temperature }\left[{ }^{\circ} \mathbf{C}\right]\end{array}$ & $\begin{array}{l}\text { Nett refrigerating } \\
\text { capacity }[\mathbf{k W}]\end{array}$ \\
\hline $349 \_07$ & 11.3 & 36.4 & 20.9 & 12.1 \\
\hline $351 \_23$ & 9.7 & 36.7 & 19.8 & 10.5 \\
\hline
\end{tabular}

After the tests the PClogs were scrutinized for factors that may explain the difference in maximum refrigeration capacity between the two software versions. Table 8 lists the most striking differences. It is suspected that especially the difference in active compressor limiter function causes the difference in observed refrigeration capacity.

\footnotetext{
1 terminology in this report: heat load $=$ nett heat load $=$ heat ingress through walls + heat production inside the unit (excl. heat production by reefer unit components, like the evap. fans)
} 
Table 8, information from PClogs that may explain the capacity difference reported in Table 7.

\begin{tabular}{|l|l|l|}
\hline software & 349_07 & $\mathbf{3 5 1 \_ 2 3}$ \\
\hline avg. Psuc & $2.64 \mathrm{bar}$ & $2.73 \mathrm{bar}$ \\
\hline avg. Pdis & $18.51 \mathrm{bar}$ & $16.67 \mathrm{bar}$ \\
\hline avg. compressor freq. & $52 \mathrm{~Hz}$ & $43 \mathrm{~Hz}$ \\
\hline avg. expansion valve opening & $59 \%$ & $54 \%$ \\
\hline $\begin{array}{l}\text { avg. economizer expansion } \\
\text { valve opening }\end{array}$ & $68 \%$ & $53 \%$ \\
\hline active compressor limiter & 2 & 4 \\
\hline
\end{tabular}

\subsection{Supply air temperature differences across the width of the container}

Fig. 6 shows the temperatures recorded in the T-bar openings as a function of nett heat load for software 0349_07 (tests 3, 5, 7, 8). Two things catch the eye:

1. The bigger the heat load the higher the temperature differences.

2. Many recorded temperatures are well below the $14.0^{\circ} \mathrm{C}$ setpoint.

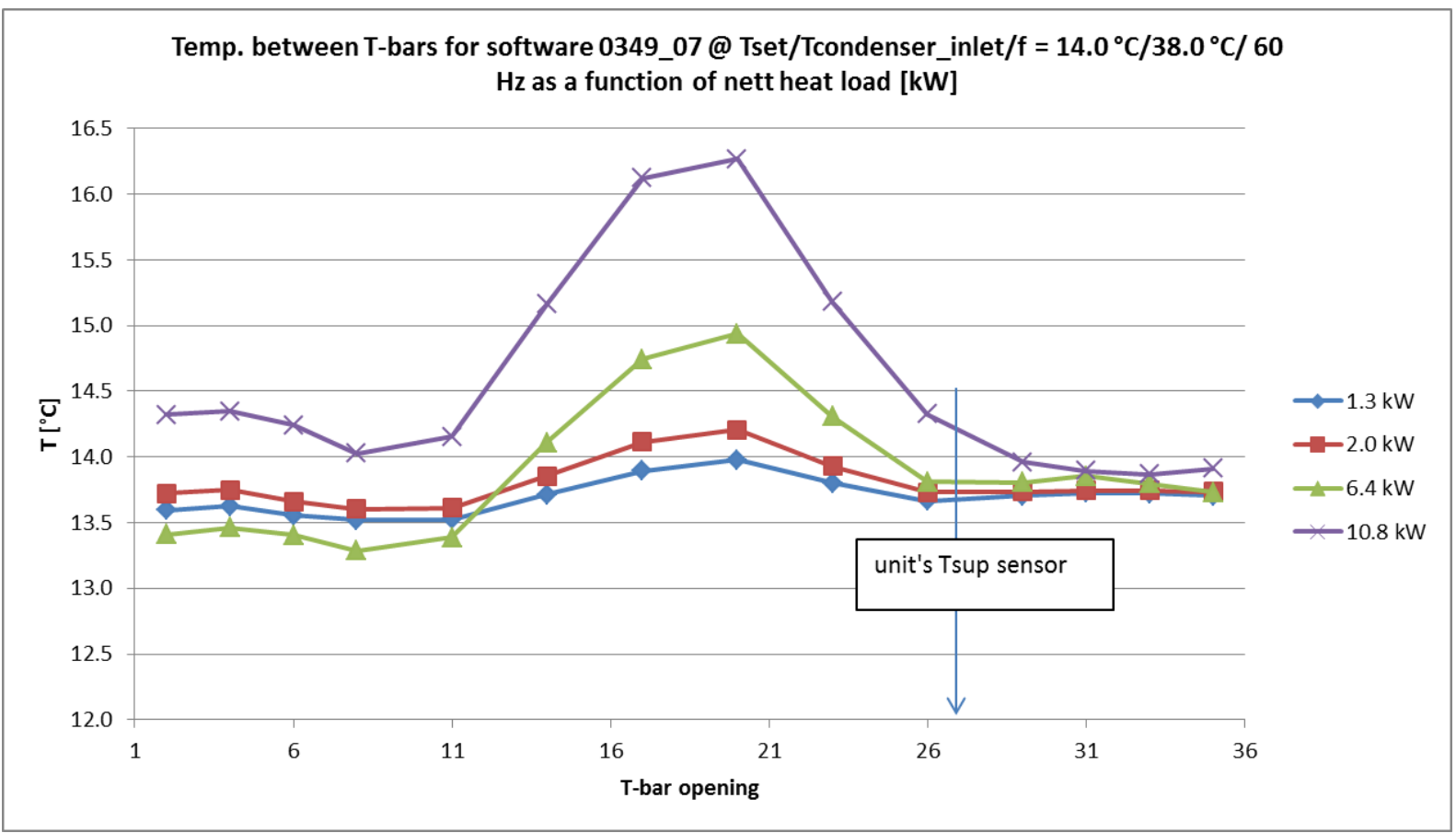

Fig. 6, air temperatures in the T-bar openings for different nett heat loads using software 0349_07 (markers mark measurements).

Fig. 7 present the results for software 0351_23 (tests 2,14,15). The difference between Fig. 6 and Fig. 7:

1. The measurement at $10.8 \mathrm{~kW}$ is missing in Fig. 7. This is because software 0351_23 lacked the refrigeration capacity to maintain the unit's supply air temperature at $14.0{ }^{\circ} \mathrm{C}$ at that heat load. 


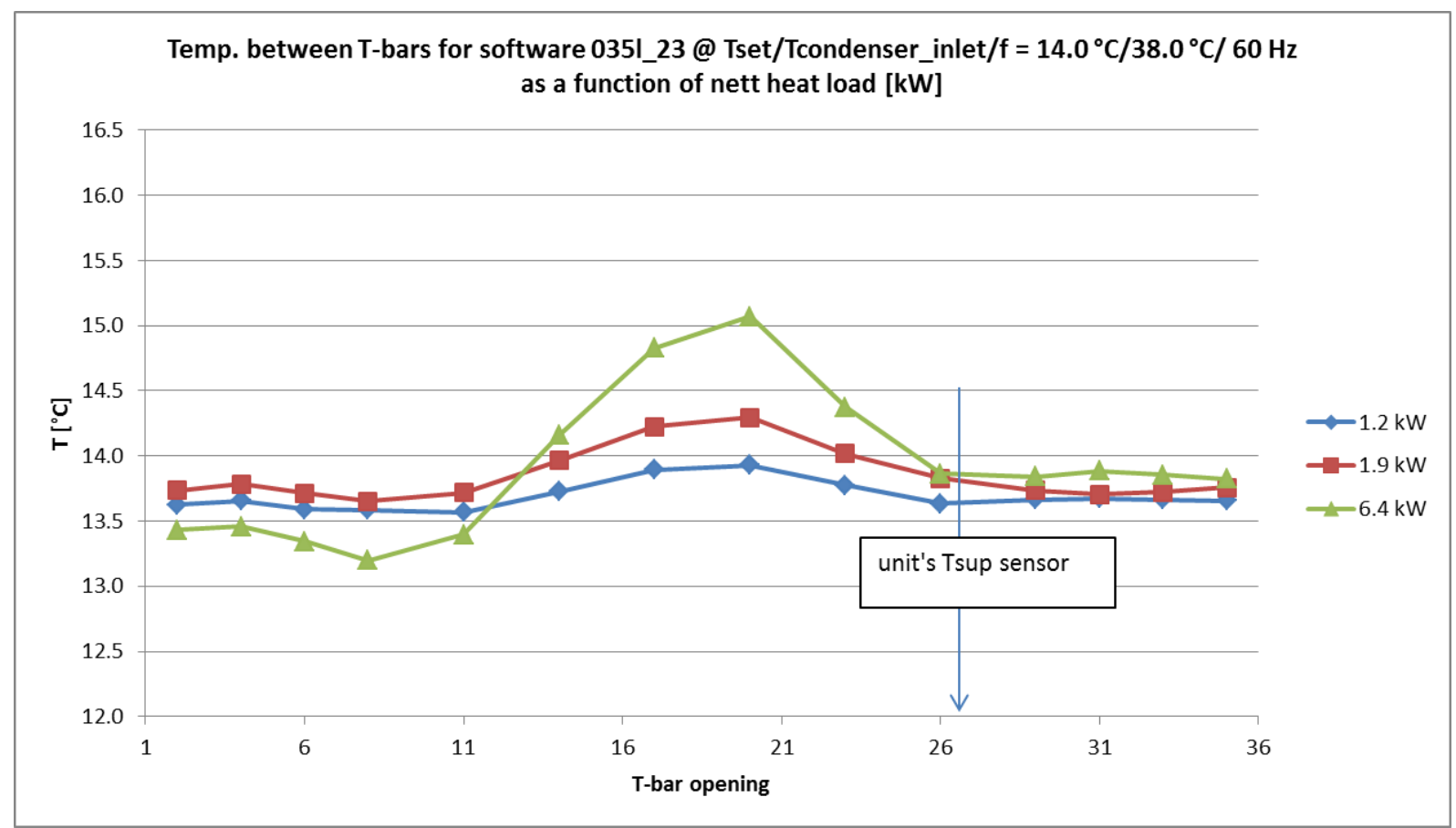

Fig. 7, air temperatures in the T-bar openings for different nett heat loads using software $0351 \_23$ (markers mark measurements).

Fig. 8 presents the air temperatures recorded in the T-bars for software 0351_23 and nett heat load of approximately $10 \mathrm{~kW}$ (tests 9,16 ), which is the maximum refrigeration capacity available at $50 \mathrm{~Hz}$. It is remarkable that at $60 \mathrm{~Hz}$ the unit is not able to bring the supply air temperature down to setpoint, while at $50 \mathrm{~Hz}$ it is. 


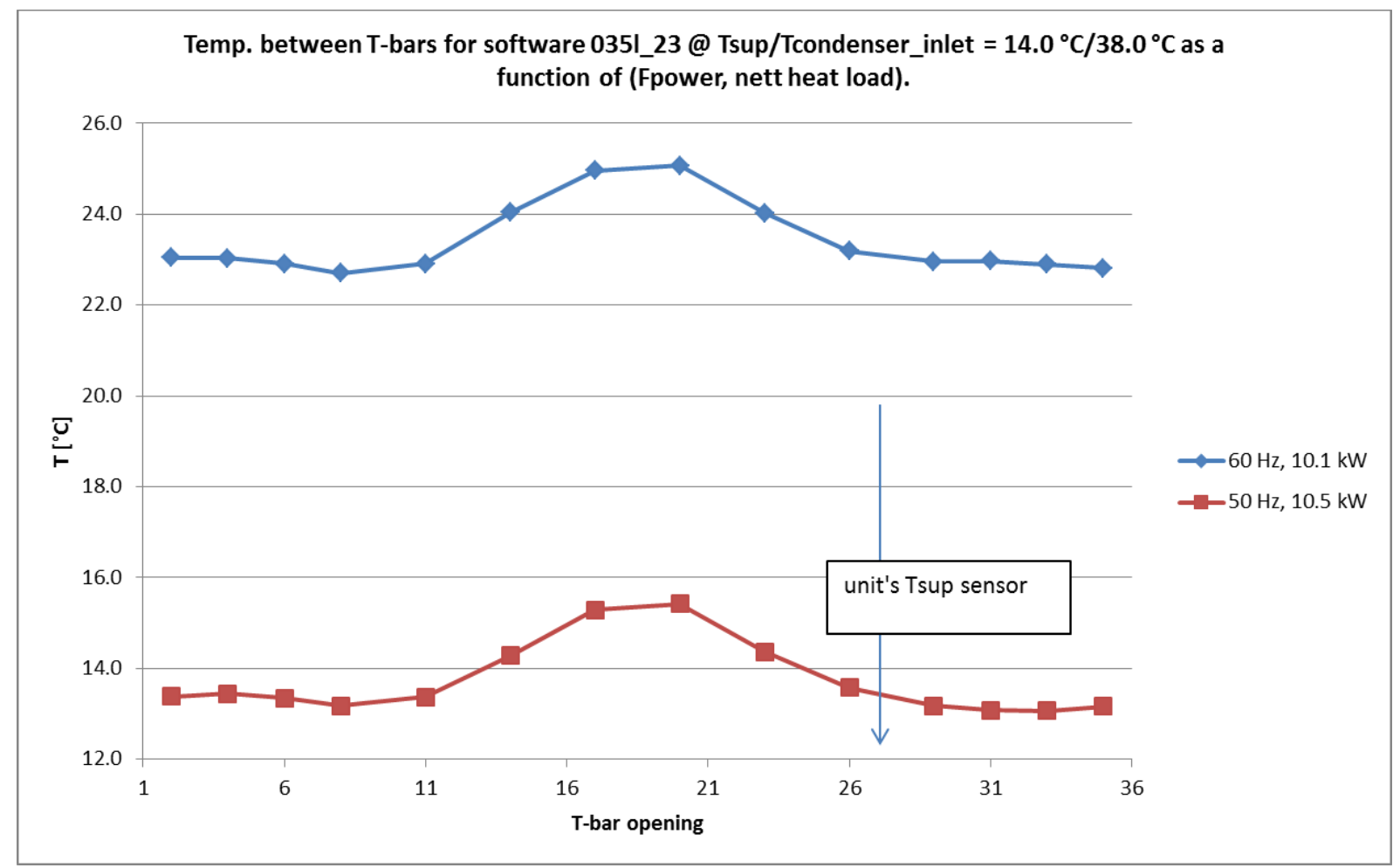

Fig. 8, air temperatures in the T-bar openings for nett heat load of approximately $10 \mathrm{~kW}$, which is the maximum refrigeration capacity available at $50 \mathrm{~Hz}$ (markers mark measurements). Warning: the data at 60 $\mathrm{Hz}$ were not collected in a proper steady state, in fact the temperatures were still on the rise in the period over which the data were evaluated.

Fig. 9 presents the results of Fig. 6 and Fig. 7 together in one figure. Clearly the observed differences between the two software versions are very limited, except when the heat load exceeds $10 \mathrm{~kW}$ where software 0351_23 fails to maintain supply air temperature at setpoint. 


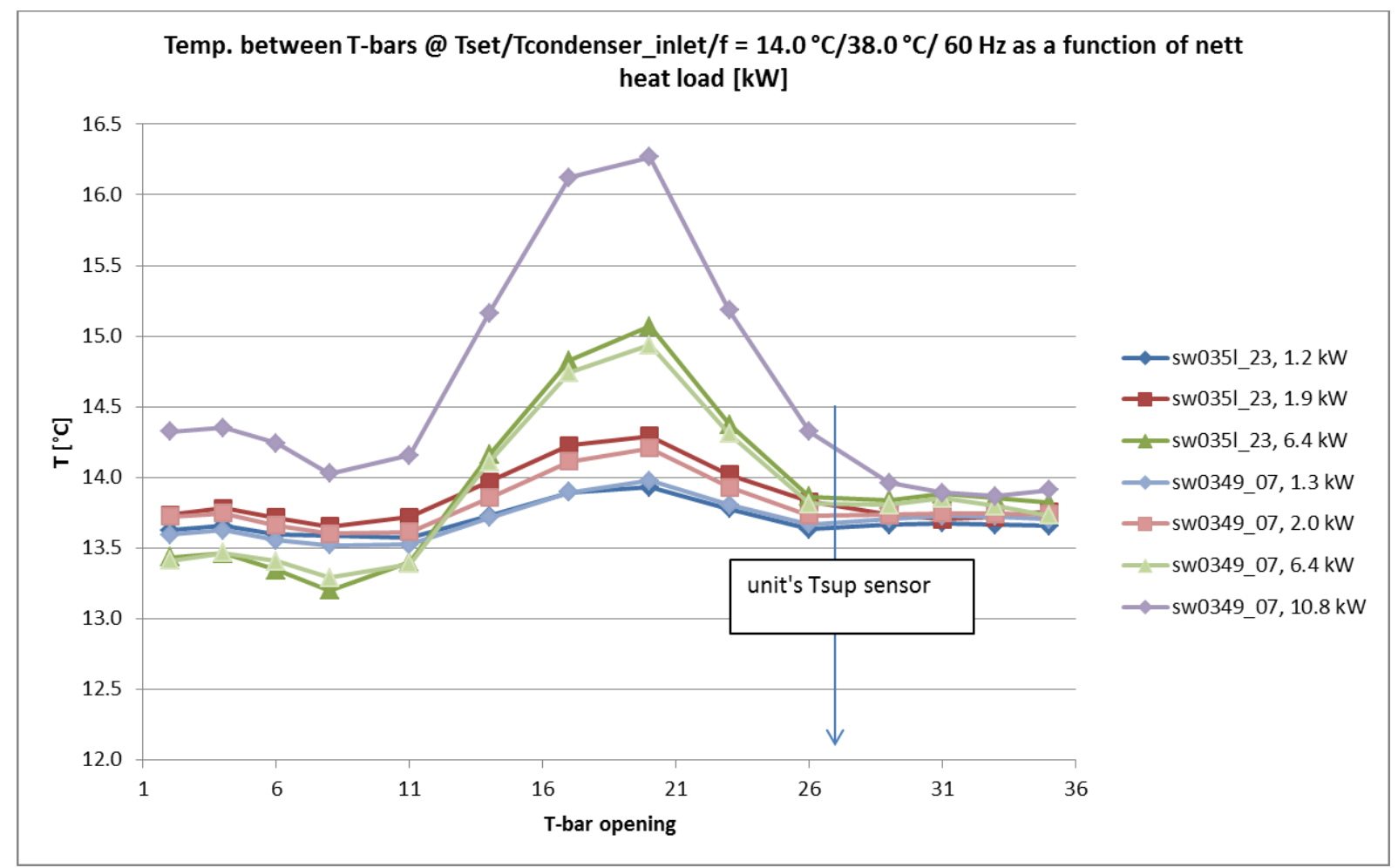

Fig. 9, air temperatures in the T-bar openings for different nett heat loads using software 0349_07 and 0351_23 (markers mark measurements).

It is worth noting that, regardless of software version, the lowest and highest air temperature in the T-bar at $6.4 \mathrm{~kW}$ heat load are 13.2 and $15.1^{\circ} \mathrm{C}$. This happens while Tset $=14.0^{\circ} \mathrm{C}$, and the unit's recorded Tsup is tightly controlled to $14.0^{\circ} \mathrm{C}$. In T-bar opening 26 , very close to the unit's supply air temperature sensor the recorded temperatures range from 13.6 to $14.3^{\circ} \mathrm{C}$. At lower ambient temperature, when heat load is approximately $0 \mathrm{~kW}$, the cross-sectional temperature differences between the T-bars are smaller (see Fig. 10, presenting the results from tests 12 and 13). 


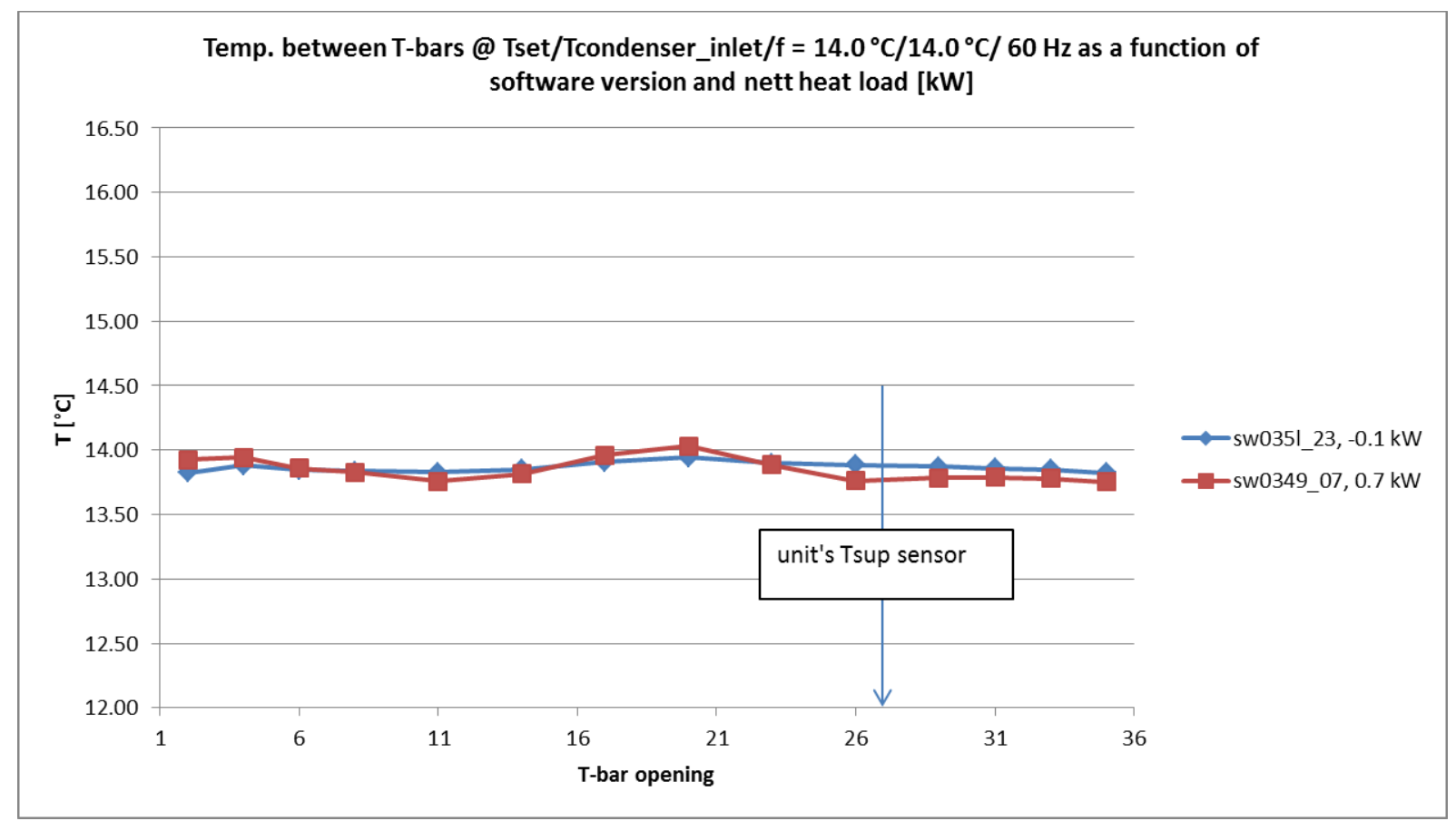

Fig. 10, air temperatures in the T-bar openings for software 0349_07 and 0351_23, both at very small nett heat load (markers mark measurements).

Finally the tests without internal heat production have been repeated at a condenser air inlet temperature of $50{ }^{\circ} \mathrm{C}$ for both software versions (tests 19 and 20). Again the difference between the two software version is negligible (see Fig. 11). 


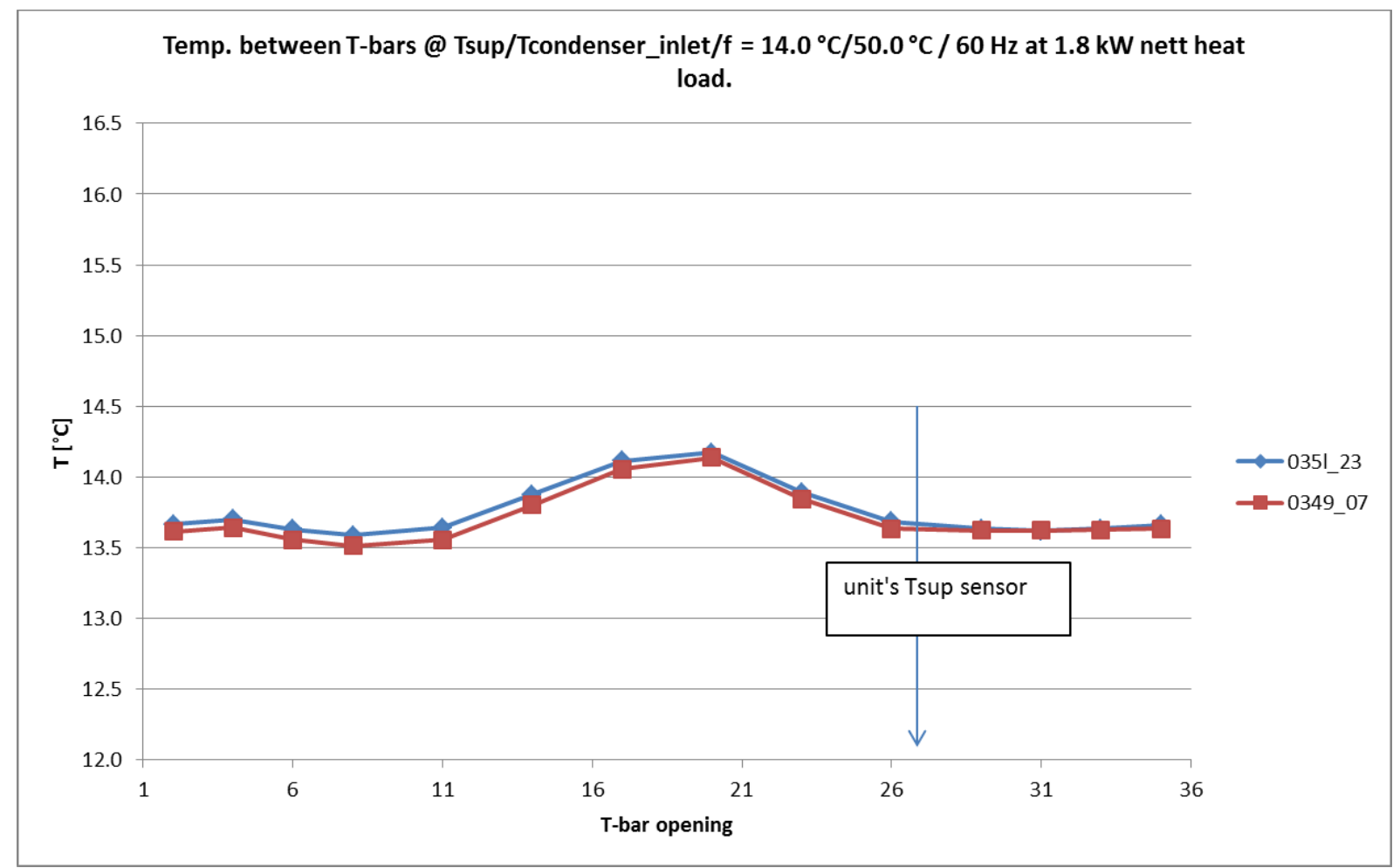

Fig. 11, air temperatures in the T-bar openings for software 0349_07 and 0351_23, both at $T_{\text {condenser_inlet }}=50$ ${ }^{\circ} \mathrm{C}$ (markers mark measurements). 


\section{Discussion}

On beforehand three possible reasons were identified why software version would affect the rate of temperature pulldown in banana shipments. In the following sections each of them is discussed individually.

Possible reason 1: change in evaporator fan speed control. It was indeed observed that only in software 0349_07 activating CA automatically disables Quest II, hence forcing the evaporator fans to high speed, regardless of heat load (section 3.2). Software 0351_23 runs Quest II control, also when the CA application is active. It is part of the Quest II logic to reduce the evaporator fan speed to low when no high heat load is observed. The algorithm relies on multiple indicators to estimate this heat load. A crucial one is the difference between Treturn and Tsupply. Quest II certainly forces evaporator fan speed to high as long as (Treturn - Tsupply) $>1.2{ }^{\circ} \mathrm{C}$, and possibly longer. Meaning that evaporator fan speed cannot affect the initial rate of temperature pulldown, when Treturn $>\left(\right.$ Tsupply $\left.+1.2^{\circ} \mathrm{C}\right)$. By heart the authors would estimate that this initial phase usually lasts approximately two days. In short: only in the later phase of the pulldown, where Treturn $\leq$ (Tsupply $+1.2^{\circ} \mathrm{C}$ ), software 0349_07 might give a faster pulldown than 0351_23 due to the difference in evaporator fan speed control.

Possible reason 2: change in maximum refrigeration capacity by modified limits imposed on maximum compressor frequency. The measured maximum refrigeration capacity with software 0351_23 is approximately $20 \%$ less than with software 0349_07 (section 3.2). It is the impression that it relates to active compressor limiters, without understanding the details of those limiters. Could this loss of refrigeration capacity cause a difference in the rate of temperature pulldown? To the knowledge of the authors in banana shipments Tsup usually reaches Tset nearly instantaneously, after which the maximum refrigeration capacity is no longer needed. Hence it is difficult to imagine how the loss of refrigeration capacity could affect the rate of banana temperature pulldown. Possibly there is a bit of an effect in exceptionally hot ambient conditions $\left(>40{ }^{\circ} \mathrm{C}\right)$. Those exceptional temperatures especially occur in reefer holds on board of vessels. But then, the maximum refrigeration capacity is especially needed in the first part of the temperature pulldown, which is usually done on terminals before loading on board. Hence it is hard to imagine that the loss of refrigeration capacity, measured at $50 \mathrm{~Hz}$, has a measurable effect on the rate of banana temperature pulldown.

An extra complication is added by the fact that during the tests for software 0351_23 a maximum refrigeration capacity of $10.5 \mathrm{~kW}$ was found at $50 \mathrm{~Hz}$ (section 3.2 , test 9), while at $60 \mathrm{~Hz}$ software 0351_23 was not at all able to maintain supply air temperature at $14{ }^{\circ} \mathrm{C}$ for a heat load of $10.8 \mathrm{~kW}$ (section 3.4. test 16), and also in test 18 at $50 \mathrm{~Hz}$ software 0351_23 was not at all able to maintain supply air temperature at $14{ }^{\circ} \mathrm{C}$ for a $10.3 \mathrm{~kW}$ heat load. Usually units have more capacity at 60 $\mathrm{Hz}$. In test 18 the unit is not able to maintain setpoint at a heat load less than the maximum refrigeration capacity. How to explain these strange observations? Could it be that software 0351_23 loses more refrigeration capacity at $60 \mathrm{~Hz}$ than at $50 \mathrm{~Hz}$ ? It's hard to imagine, but yet the data point in that direction. Could it be that something in the machine changed during the tests? 
The difference between the results of tests 9 and 18 indicates so, but it contradicts with the fact that tests 2 and 17 yielded virtually identical results. Altogether it remains uncertain.

Possible reason 3: change in supply air temperature distribution across the width of the container, due to changes in superheat control. Supply air temperature differences across the width of the container of up to $2.5^{\circ} \mathrm{C}$ have been observed (section 3.4). Most likely the inhomogeneity in supply air temperature across the width of the T-bar floor is caused by inhomogeneous air flow across the coil: higher air flow in the centre, and lower at both sides. This is certainly not good for the temperature homogeneity of the carried commodity. But no effect of software version was observed. 


\section{Conclusions}

1. Activating CA forces control mode to non-Quest in software 0349_07, while in software 0351_23 control mode stays Quest II. Consequentially software 0349_07 runs high speed evaporator fans, while software 0351_23 adjust evaporator fan speed to heat load. This may only have an impact on the rate of temperature pulldown in the later stages of the pulldown, as in Quest II the criterion 'Treturn $>$ (Tsupply $+1.2^{\circ} \mathrm{C}$ )' is reason to force the evaporator fan speed to high.

2. It looks like software 3349_07 yields approximately $20 \%$ more refrigeration capacity than software 0351_23. Such at Tamb $=38^{\circ} \mathrm{C}$, Tsup $=14{ }^{\circ} \mathrm{C}$, and $50 \mathrm{~Hz}$ power supply. It is not believed this difference has much impact on the rate of temperature pulldown in banana shipments, because usually in those shipments the unit hardly needs to call upon the maximum refrigeration capacity.

3. No indication was found that supply air temperature distribution across the width of the container is affected by software version. 


\section{Recommendations}

Both the observed loss of refrigeration capacity, and the reduced evaporator fan speed, have the potential to reduce the rate of temperature pulldown in banana shipments. But both factors are believed to be very small. To find out which one is strongest, it is recommended to perform a 'big data' analysis on numerous Starcare CA downloads (RCM data) of software 0349_07 and later software versions for banana shipments with two criteria:

1. Time till Treturn drops below (Tsupply $+1.2^{\circ} \mathrm{C}$ ).

2. Time till Treturn drops below Tsupply $+0.5^{\circ} \mathrm{C}$.

The time till Treturn drops below Tsupply $+0.5^{\circ} \mathrm{C}$ is a criterion to flag the "pulldown completed'. If the issue relates to the evaporator fan speed control then the time between the moment Treturn drops below (Tsupply $+1.2^{\circ} \mathrm{C}$ ) and the moment Treturn drops below Tsupply $+0.5^{\circ} \mathrm{C}$ is shorter for software 0349_07. If the issue relates to maximum refrigeration capacity then the time till Treturn drops below (Tsupply $+1.2{ }^{\circ} \mathrm{C}$ ) is shorter for software 0349_07. Ask Starcool if there is a reasonable explanation and justification for the observed loss of refrigeration capacity in software 0351_23.

The difference in supply air temperature across the width is not good for the temperature homogeneity of the carried commodity and deserves to be discussed with Starcool. 


\section{Acknowledgements}

We are grateful to Maersk Line, represented by Morten Baerentz, for the kind cooperation, for the financial support, and for making the required test container and genset available. 